\title{
THE EMPIRICAL ANALYSIS OF TECHNOLOGY AND FOREIGN DIRECT INVESTMENTS
}

\author{
Selim Corekcioglu
}

$\mathrm{PhD}$ student

Szent Istvan University, PhD school of Management and Business Administration

E-mail: corekcioglu.selim@phd.uni-szie.hu

\begin{abstract}
The main aim of this study is to analyze the relationship between foreign direct investment and R\&D spending using panel co-integration methods for upper middle-income economies and high-income economies. A larger level of investment is needed to increase the capital stock in order to ensure growth, but the typically low savings rate makes this difficult to achieve. Theoretically, it is expected that foreign direct investments would solve the saving inadequacy problem of the target country leading to economic growth by increasing capital accumulation.

In this study, Levin Liu Chu and Pesaran Shin Unit Root tests, Pedroni panel co-integration tests was applied. According to the co-integration analysis, foreign direct investment and R\&D spending move together in the long run. The results of the panel co-integration test which examines the long-term relationship, showed that R\&D spending has stronger effect on foreign direct investment.

In a globalized world, technology is one of the most important determinant of competition among countries. Technology improves profitability and competitiveness by increasing productivity. It can be seen that technological developments are coupled with economic growth throughout the history. With the involvement of technology transfers in production, added value will increase in manufacturing industry, so this will accelerate the process growth. Infrastructural investments, education system reforms tax reduction should be provided by government to promote technology level. The findings of this paper underline that capital accumulation and foreign direct investment are very important for countries in terms of development.
\end{abstract}

Keywords: Foreign Direct Investment, Technology, Growth, Trade

JEL classification: B17, F21

LCC: $H G 4538$

\section{Introduction}

There are significant differences in the long-term economic growth performance of countries. Differences in long-term growth can be partially explained by economic factors. Some of these factors are as follows: demographic factors, technological development, natural resources, geography and climate; political, social and cultural factors. These factors are not independent of each other and their previous levels. For example, the political stability in any country affects the economic determinants of growth or the technological development in the country in the previous years will accelerate future technological developments.

Structural transformation reforms, which encompass environmental dimensions such as macroeconomic stability, capital accumulation, foreign trade developments and the market economy, have very important role on sustained development. 
Saving rate is one of the most important factor for economic growth, but the high rate of savings is not enough for economic growth. It is also necessary to transform the saving into the productive investment. New investments increase the accumulation of physical capital, such as machinery, equipment, or the installation of a new factory. New investments lead to an increased production capacity and a higher production level.

The low level of income cause low savings and therefore capital accumulation and investments will be inadequate in developing countries. Due to the lack of capital, these economies cannot achieve sustainable economic growth and fail to make the necessary physical investments. This problem, which is confronted by underdeveloped countries, is called as the vicious circle of poverty (Samuelson \& Nordhaus, 2001, p. 528). One solution for the insufficient saving problem are foreign borrowing and foreign direct investment. If the internal savings are inadequate, countries either turn to external financial sources or try to attract more foreign investment in order to catch up with a certain growth rate and realize the sufficient investment rate.

With the liberalization of capital movements, significant increase in capital flows can be seen among the countries. International capital movements are divided into two groups: portfolio investments and foreign direct investment. Portfolio investments represent the purchase of securities, for example bonds or stocks from any foreign country. Direct foreign capital investment means either that a new company is established in a foreign country, or the purchase of an existing company or the capital increase.

Foreign direct investment led economic growth by solving the inadequacy problem of capital accumulation of the countries (Song, Makhija, \& Lee, 2014). In addition, foreign capital brings advanced management knowledge and production technology to the target country, and foreign direct investment indirectly affects economic growth in the following ways (de Mello, 1997): transfer of technology, training of the workforce, acquisition of skills, new management techniques and organizational arrangements. These provide an accumulation of knowledge in the host country and affects economic growth indirectly.

It is obvious that foreign capital will flow towards countries with high growth potential under economic and political stability. Because foreign capital aims to achieve high returns, undoubtedly, when making an investment decision, the investor considers the growth potential and risks of the country of destination. For this reason, it is obvious that low-risk countries with high growth rate or growth potential will attract more foreign capital.

\section{Overviews On FDI Analyses}

Studies examining the relationship between foreign direct investment and economic growth differ in terms of the methodology and outcome. Below, some studies related to the relationship between FDI and other variables such as technology gross domestic product etc. have been evaluated in terms of the methods used and the results obtained.

Abbes studied the impact of foreign direct investment on economic growth. Using panel data methods which includes co-integration test and granger causality tests, 65 countries were analyzed. According to the results of the study, the causality is unidirectional from FDI to GDP (Abbes, Mostéfa, Seghir, \& Zakarya, 2015).

Kargi analyzed Turkish Economy by using Structural Breakage Analysis (SBA) and Long Termed Co-integration Analysis (LTCA) for the period 1980-2012. His analysis was based on 
the effect of portfolio investments and foreign direct investments on the growth. The result of structural breakage analysis showed that there is no relation between foreign direct investments and growth. The paper also revealed that both portfolio investments and foreign direct investments have positive effect on economic growth (Kargi, 2014).

Sandhu explored the effect of gross domestic product, inflation, exchange rate, trade openness, India interest rate in and US interest rate by using time series analysis. Time interval was chosen between 1994-2014. In the analysis it was found that although four variables which are trade openness, interest rate in USA, exchange rate and gross domestic product are significant, two variables which are inflation and India interest rate are insignificant. Result of findings showed that there is complementarity relation between FDI and four significant variables (Sandhu \& Gupta, 2016).

Wilson and Baack examined the link between FDI and advertisement. Four well known business magazines in U.S.A were used to see effect of advertisement on FDI. Time interval covered 55 months from January 2007 to July 2011. 31 countries which were used in analysis were classified according to their income such as lower-middle income, Upper-middle income and higher income. Then, exploratory factor analysis was used to identify factors such as natural resources, economic governance, knowledge resources, infrastructure and market attractiveness and which are related to FDI advertisement. According to results of the paper Upper middle income countries mainly focused on governance promoting, attractiveness of their market knowledge resources economic, countries which has lower middle income level mainly focused on economic governance and countries which has higher income level mainly focused on knowledge resources (Wilson \& Baack, 2012).

Sunde studied for South Africa countries between 1990-2014. For understanding economic growth, FDI and exports relationship, autoregressive distributed lag model, error correction model and Granger causality test has been carried out for the countries. Study result showed the causality is unidirectional from economic growth to FDI, bidirectional from economic growth to export and unidirectional from FDI growth to export (Sunde, 2017).

Study of Afşar (2008) on Turkey's economy shows that there is unidirectional causality between foreign direct investment and GDP growth for Turkey's economy. It means that while FDI has statistically significant effect on GDP, GDP has not statistically significant effect on FDI (Afşar, 2008).

In the article of Cho, the author examine the relation between foreign direct investment (FDI) and income distribution for 7 Southeast Asia economies from 1990 to 2013. According to the results of panel data analysis, FDI increases income inequality in the host countries in the short term, while it decreases in the long term (Cho \& Ramirez, 2016).

In 2013, Almfraji made a detailed literature review on FDI and economic growth. The paper which covers 1998 - 2012 revealed that in the most of cases there is a positive relationship between FDI and economic growth, but in some cases the effect is negative or insignificant. Besides, it was investigated other factors which influence FDI and economic growth. Human capital, political environment, open trade regimes, financial markets have positive effect on the FDI and economic growth relation; but the inadequate technical infrastructure has negative effect on this relation (Almfraji \& Almsafir, 2014).

In another study, entry way of multinational companies into host countries, its technological development effects and government policies were discussed. If the technology transfer costs 
are low multinational companies prefer merger and acquisition, if not they prefer sudden entry. In developing countries, while multinational companies enter the market they mostly prefer merger and acquisition. To protect local companies, host country government impose some restriction on multinational companies in the sectors which are required high-cost technology transfer, while they can freely compete with local companies in the sectors required low-and medium-technology transfer. At the end it was concluded that, foreign direct investment increase technology level and an increase in technology level lead to welfare maximization (Ghebrihiwet, 2017).

The paper of Ekmekçi and Ansal analyzes the impact of technology competencies of local companies on the knowledge transfer while local companies are having supplier-customer relationship with multinational companies branches in the host country. It is concluded that local companies that can produce in high quality standards and have a vision and strategy based on innovation can be placed in a more central position in the supply chains of customers and thanks to their collaborations based on long productive product and technology development. It is also important that these local companies should be supported by the government and this policy will effect economy positively (Ekmekçi \& Ansal, 2009).

(Ha \& Giroud, 2015) conducted a study on FDI, technology and multinational enterprises (MNE). According to paper FDI which is made by MNE has influence on technology level (Ha \& Giroud, 2015).

In another article it was asserted that technological externalities are very important for domestic companies. However, in order to be used this technology by domestic companies, some problems must be solved. financial issues constitute the basis of these problems. If the financial issues which domestic companies encounter are solved, technological development will be accelerated in a country (Eapen, Yeo, \& Sasidharan, 2019).

When the literature is examined, it can be concluded that technology level and FDI have an impact on welfare and growth. Although some studies found insignificant relation between FDI and technology, most of these studies showed that there are relation between FDI and technology. By considering these, it is very important to understand relation between FDI and technology to catch sustainable growth.

\section{Method and Data Set}

In this study panel data cointegration analysis is used to see if there is co-integration between two variables or not. Panel data is generated by bringing together time series observations of economic units in cross section form. This method which includes both the cross section analysis and time series analysis provide better econometric analysis for any econometric model (Baltagi, 2005). The model for the panel data can be expressed as follows;

$Y_{\mathrm{it}}=\rho_{\mathrm{i}} Y_{\mathrm{it}-1}+\delta_{\mathrm{i}} \mathrm{X}_{\mathrm{it}}+\varepsilon_{\mathrm{it}}$

In the equation $\mathrm{i}=1, \ldots, \mathrm{N}$ is the index for cross-sectional units and $\mathrm{t}=1, \ldots, \mathrm{T}$ show the point of observation for the unit. $\mathrm{N}$ is the number of units in the model; $\mathrm{T}$ is the number of observations per unit, eit is the error term for the $\mathrm{i}$ at time $\mathrm{t}$. cit the error term is white noise disturbance. If $|\rho \mathrm{i}|<1, \mathrm{Yi}$ is the stationary, and if $|\rho \mathrm{i}|=1$, Yi contains a unit root.

In the panel data analysis, Levin Lin - Chu - Im Pesaran Shin unit root tests are commonly used (Im, Pesaran, \& Shin, 2003; Levin, Lin, \& James Chu, 2002). The LLC and IPS unit root tests 
differ due to different assumptions and test statistics used for the $\rho$ i coefficient in equation 1. In the LLC unit root test, $\rho$ i coefficients are assumed to be same for the panel cross sections. This can be expressed as $\rho i=\rho$ for all $i$. In the IPS unit root test, it is assumed that the $\rho i$ coefficients are changed for the cross sections of the panel data. The basic equation for LLC and IPS unit root tests, based on the ADF principles for $\alpha=\rho-1$, can be expressed as:

$Y_{i t}=\alpha_{i} Y_{i t-1} \sum_{j=1}^{p_{i}} \beta_{i j} \Delta Y_{i t-j}+X_{i t} \delta+\varepsilon_{i t}$

In this model, null and alternative hypotheses for the LLC unit root test are as follows.

$\mathrm{H}_{0:} \alpha_{\mathrm{i}}=0$

$\mathrm{H}_{0}: \alpha_{\mathrm{i}}=\alpha<0$

As it is seen from the hypotheses, in the LLC unit root test, it is tested whether the time series of each cross-sectional unit of the panel includes unit root or not, in other words it is tested to understand if the time series of each cross-sectional unit is stationary or not.

The zero and alternative hypotheses for the IPS unit root test are as follows:

$$
\begin{aligned}
\mathrm{H}_{0} & \alpha_{\mathrm{i}}=0, \forall_{\mathrm{i}} \\
\mathrm{H}_{\mathrm{A}}: & \alpha_{\mathrm{i}}=0 \mathrm{i}=1,2, \ldots, \mathrm{N}_{1} \\
: & \alpha_{\mathrm{i}}<0 \mathrm{i}=\mathrm{N}+1, \mathrm{~N}+2, \ldots, \mathrm{N}
\end{aligned}
$$

What is expressed in the null hypothesis is that all cross sections series of the panel contain unit roots. In the alternative hypothesis, it is expressed that some of the cross sections series or all of cross sections series are stationary.

In the LLC unit root test, the standard t statistic is used for the normal distribution of the standard $\alpha$ i coefficient. In the IPS unit root test, the arithmetic means of the t statistics which is calculated for the cross sections is used.

The co-integration relationship shows that there is a long-run relationship between the series, despite external shocks affecting the variable series. So, while testing correlation of the two variables, it will also be examined whether there is a common co-integration among the variables or whether there are any deviations there. If the series are not stationary, they must be transformed. So, the cointegration analysis developed by Pedroni can be used for this (Pedroni, 1999, 2004). The Pedroni cointegration test shows individual heterogeneity of fixed effects in the panel. Pedroni coordination analysis can be expressed as follows.

$\mathrm{Y}_{\mathrm{it}}=\alpha_{\mathrm{i}}+\delta_{\mathrm{it}}+\beta_{\mathrm{i}} \mathrm{X}_{\mathrm{it}}+\mathrm{e}_{\mathrm{it}}$

$\mathrm{Y}$ and $\mathrm{X}$ are variables are stationary in the first difference. $\alpha_{\mathrm{i}}$ and $\delta i$ parameters show the individual effects of the cross sections.

In the Pedroni co-integration analysis, the existence of a cointegrative relationship between variables $\mathrm{Y}$ and $\mathrm{X}$ is tested by stationarity tests of $\mathrm{e}_{i t}$ error terms. Stationarity tests of error terms are as follows. 


$$
\begin{aligned}
& \mathrm{e}_{\mathrm{it}}=\rho_{\mathrm{i}} \mathrm{e}_{\mathrm{it}-1}+\mathrm{u}_{\mathrm{it}} \\
& e_{i t}=\rho_{i} e_{i t-1}+\sum_{j=1}^{p_{i}} \psi_{i j} \Delta e_{i t-j}+u_{i t}
\end{aligned}
$$

In the hypothesis tests, it is tested whether the $\rho_{\mathrm{i}}$ coefficient is equal to 1 or not. So, the null hypothesis for Pedroni co-integration states that there is no correlation between $\mathrm{Y}$ and $\mathrm{X}$ variables. There are two cases in the alternative hypothesis. The first case is that for all cross sections the $\rho_{i}$ coefficients are different. In the $6^{\text {th }}$ equation of Pedroni co-integration analysis, the null and alternative hypotheses for the $\rho_{\mathrm{i}}$ coefficient can be shown as follows.

$$
\begin{aligned}
& H_{0:} \rho_{i}=1 \\
& H_{a:} \rho_{i}=\rho<1
\end{aligned}
$$

The second case is that some of the $\rho_{\mathrm{i}}$ coefficients are different. In this case, the whole-panel co-integration is examined. In the $7^{\text {th }}$ equation of Pedroni co-integration analysis, the null and alternative hypotheses for the $\rho_{\mathrm{i}}$ coefficient can be shown as follows.

$$
\mathrm{H}_{0:} \rho_{\mathrm{i}}=1
$$

$\mathrm{H}_{\mathrm{a}:} \rho_{\mathrm{i}}<1$

In the Pedroni co-integration analysis, there are 7 tests seven test statistics (Pedroni, 1999). The first four of these statistics are intra-group the group and other three of these statistics are between the groups. The intra-group test statistics for the Pedroni correlation test are variance ratio, non-parametric Phillips and Perron type $\rho$, nonparametric Phillips and Perron type $t$ and Dickey-Fuller type $t$ statistics respectively. The null and alternative hypothesis showed in 8 can be used for this. The second category test statistics of the Pedroni panel analysis are Phillips and Perron type $\rho$, Phillips and Perron type $t$ and Dickey Fuller type $t$ statistics \{Citation\}. The null and alternative hypothesis showed in 9 can be used for this. Co-integration analysis makes it possible to examine the long-term relationship between variables.

In order to examine the relationship between foreign direct investment and technology, the foreign direct investment net inflows (US Dollar) and research and development expenditure (\% of GDP) was used as in this study. Time period examined is from 2000 to 2014. Analyzes were conducted in order to see the effect of technology and investment relationship on different country groups. Upper middle-income economies and high-income economies were selected as country groups ("World Bank Country and Lending Groups - World Bank Data Help Desk," n.d.). Due to the fact that some countries do not have data between 2000-2014, all countries are not included in analysis. high-income economies are United States, Ireland, Singapore, Netherlands, Austria, Finland, Germany, Canada, United Kingdom, France, Japan, Italy, Korea Republic, Spain, Cyprus, Slovenia, Portugal, Estonia, Czech Republic, Slovak, Trinidad and Tobago, Lithuania, Latvia, Poland, Hungary and upper middle-income economies are Croatia, Argentina, Turkey, Russian Federation, Romania, Mexico, Brazil, Kazakhstan, China, Bulgaria, Colombia, Belarus, Serbia, Macedonia, Azerbaijan. The data were obtained from the World Bank database ("Indicators | Data," n.d.).

\section{Estimation and Results}

The results of the FDI and R\&D and the first differences of FDI and GDP for the Levin Liu Chu (LLC) and Im, Pesaran and Shin (IPM) unit root tests are presented in tables 1-a, 1-b and $2-\mathrm{a}, 2 \mathrm{~b}$, respectively. While values with * indicates statistical significance level (probability) at $1 \%$ values with $* *$ indicates statistical significance level (probability) at $5 \%$. 
The results of the LLC for high-income group countries show that FDI level is stationary for intercept, intercept and trend, none while R\&D Exp. (Level) is not. According to IPM test for High-income group countries, although FDI (Level) variable are stationary R\&D Exp. (Level) is not. But first difference of variables which are $\triangle F D I \Delta R \& D$ Exp. are stationary for both LLC tests and IPM tests.

As LLC test is executed for upper-middle-income group countries, while FDI(Level) is stationary for intercept, intercept and trend R\&D Exp. (Level) is only stationary for intercept and trend. The results of the IPM test also indicates that although FDI (Level) is stationary R\&D Exp. (Level) is not. However, both FDI and R\&D are stationary at their first difference. If all variables are stationary at their first differences, test results will not be spurious.

Table: 1-a Levin Liu Chu Unit Root tests (High-income group countries)

\begin{tabular}{|l|c|c|c|}
\hline Variables & Intercept & Intercept and Trend & None \\
\hline FDI (Level) & $-5.62709^{*}$ & $-6.62245^{*}$ & $-2.57383^{*}$ \\
\hline R\&D Exp. (Level) & 1.29968 & -1.26837 & 6.26851 \\
\hline$\Delta$ FDI & $-17.5929^{*}$ & $-14.8736^{*}$ & $-23.5436^{*}$ \\
\hline$\Delta$ R\&D Exp. & $-6.75658^{*}$ & $-9.69257^{*}$ & $-9.01598^{*}$ \\
\hline
\end{tabular}

Source: Own Research

NOTES: Values with * indicates significant at $1 \%$

Table: 1-b Levin Liu Chu Unit Root tests (Upper-middle-income group Countries)

\begin{tabular}{|l|l|l|l|}
\hline Variables & Intercept & Intercept and Trend & None \\
\hline FDI (Level) & $-3.68021^{*}$ & $-5.32111^{*}$ & -0.83195 \\
\hline R\&D Exp. (Level) & 0.44351 & $-3.69117^{*}$ & 4.41385 \\
\hline$\Delta$ FDI & $-13.2943^{*}$ & $-12.0405^{*}$ & $15.8059^{*}$ \\
\hline$\Delta$ R\&D Exp. & $-11.1785^{*}$ & $-11.5437^{*}$ & $-10.8825^{*}$ \\
\hline
\end{tabular}

Source: Own Research

NOTES: Values with * indicates significant at $1 \%$

Table: 2-a Im, Pesaran and Shin Unit Root Tests (High-income group countries)

\begin{tabular}{|l|l|l|}
\hline Variables & Intercept & Intercept and Trend \\
\hline FDI (Level) & $-4.67669^{*}$ & $-3.58952^{*}$ \\
\hline R\&D Exp. (Level) & 4.30646 & 0.31065 \\
\hline$\Delta$ FDI & $-15.7952^{*}$ & $-13.7339^{*}$ \\
\hline$\Delta$ R\&D Exp. & $-6.20857^{*}$ & $-6.44637^{*}$ \\
\hline
\end{tabular}

Source: Own Research

NOTES:Values with * indicates significant at 1\%

Table: 2-b Im, Pesaran and Shin Unit Root Tests (Upper-middle-income group Countries)

\begin{tabular}{|l|l|l|}
\hline Variables & Intercept & Intercept and Trend \\
\hline FDI (Level) & $-1.98923^{* *}$ & $-2.03897^{* *}$ \\
\hline R\&D Exp. (Level) & 1.90072 & -1.38238 \\
\hline$\Delta$ FDI & $-13.2943^{*}$ & $-7.01063^{*}$ \\
\hline$\Delta$ R\&D Exp. & $-8.54996^{*}$ & $-7.16576^{*}$ \\
\hline
\end{tabular}

Source: Own Research

NOTES: Values with * indicates significant at 1\%; Values with ** indicates significant at 5\% 
The results of Pedroni test for FDI and R\&D variables can be seen in table 3-a, 3-b and table 4a, 4-b. Table 3-a and 4-a shows statistics and probability of intra dimension results and Table 3-b and 4-b show statistics and probability of inter dimension results. The first three of the four tests in the first category are non-parametric tests. The first test is similar to variance ratio statistic. The second is similar to the Phillips-Peron (PP) statistic (rho) and the third statistic is similar to the PP (t) statistic. The fourth statistic is a parametric statistic similar to the Augmented Dickey Fuller (ADF) (t) statistic. In the second category, the three tests are similar to the PP (rho) statistic, while the other two are similar to the PP (t) and ADF (t) statistics(Güvenek \& Alptekin, 2010). As it is seen table 3-a and table 3-b, probability of seven statistics are less than $\% 5$. It means that they are statistically significant. As a result of these tests, there is a long-term relationship between FDI and R\&D. For high-income group countries, FDI and R\&D move together in the long run and there is a co-integration relationship between them. Table 4-a and 4-b also indicates similar result for Upper-middle income group countries. Six of the seven statistics which are Panel v Panel $\rho$, Panel PP, Panel ADF, Group PP, Group ADF have statistical significance, because their probability less than $\% 5$. FDI and R\&D move together in the long run and there is a co-integration relationship between them.

Table: 3-a Pedroni Intra Dimension Results (High-income group countries)

\begin{tabular}{|l|c|c|}
\hline Variables & Statistics & Probability \\
\hline Panel $\mathrm{v}$ & 1.669085 & 0.0476 \\
\hline Panel $\rho$ & -4.367186 & 0.0000 \\
\hline Panel PP & -6.334024 & 0.0000 \\
\hline Panel ADF & -6.397681 & 0.0000 \\
\hline
\end{tabular}

Source: Own Research

Table: 3-b Pedroni Inter Dimension Results (High-income group countries)

\begin{tabular}{|l|c|c|}
\hline Variables & Statistics & Probability \\
\hline Group $\rho$ & -2.305535 & 0.0106 \\
\hline Group PP & -10.09653 & 0.0000 \\
\hline Group ADF & -10.64977 & 0.0000 \\
\hline
\end{tabular}

Source: Own Research

Table: 4-a Pedroni Intra Dimension Results (Upper-middle income group countries)

\begin{tabular}{|l|c|c|}
\hline Variables & Statistics & Probability \\
\hline Panel v & 4.951872 & 0.0000 \\
\hline Panel $\rho$ & -3.067270 & 0.0011 \\
\hline Panel PP & -9.081384 & 0.0000 \\
\hline Panel ADF & -8.244650 & 0.0000 \\
\hline
\end{tabular}

Source: Own Research

Table: 4-b Pedroni Inter Dimension Results (Upper-middle income group countries)

\begin{tabular}{|l|c|c|}
\hline Variables & Statistics & Probability \\
\hline Group $\rho$ & -0.282849 & 0.3886 \\
\hline Group PP & -4.890746 & 0.0000 \\
\hline Group ADF & -5.738863 & 0.0000 \\
\hline
\end{tabular}

Source: Own Research 
Panel stationary analysis shows that the series of foreign direct investment and research and development expenditure variables are stationary at the first differences. Therefore, analysis results will not be spurious. The results of the Pedroni test show that there is a long-run relationship between foreign direct investment and research and development expenditure in both high-income group countries and upper-middle income group countries.

\section{Conclusion}

Foreign direct investments are expected to solve the problem of inadequate capital accumulation of the target country. On the other hand, foreign direct investment will flow to countries with potentially high growth performance having economic and political stability.

In this study, the relationship between FDI and R\&D spending was checked for upper middleincome economies and high-income economies by using panel co-integration tests methods. According to the results of Pedroni panel co-integration analysis, foreign direct investments and $R \& D$ variables have long-term relationship in upper middle-income economies and highincome economies.

Increase in technological investments boost foreign direct investment and FDI leads to economic growth because it creates an increase in investment volume. In addition, foreign capital investment brings advanced knowledge and technology to the target country. It means that FDI also has an impact on economic growth. Foreign investors, especially those operating in technology-intensive sectors, need educated qualified workers. Therefore, the education system need to be reformed in order to provide qualified personnel to these sectors as well as to ensure the technological development in the country. It is necessary to determine the requirements, for instance inadequacy of technical infrastructure, tax issues etc, to promote technology. Accordingly, government should support companies by providing investment such as grants and interest subsidies tax reduction.

\section{References}

1. Abbes, S. M., Mostéfa, B., Seghir, G., Zakarya, G. Y. (2015). Causal Interactions between FDI, and Economic Growth: Evidence from Dynamic Panel Co-integration. Procedia Economics and Finance, 23, 276-290.

2. Afşar, M. (2008). The Causality Relationship Between Economic Growth and Foreign Direct Investment In Turkey. Selçuk Üniversitesi Sosyal Bilimler Enstitüsü Dergisi, $0(20), 1-9$.

3. Almfraji, M. A., Almsafir, M. K. (2014). Foreign Direct Investment and Economic Growth Literature Review from 1994 to 2012. Procedia - Social and Behavioral Sciences, 129, 206-213.

4. Baltagi, B. H. (2005). Econometric Analysis of Panel Data (3rd ed).

5. Cho, H., Ramirez, M. (2016). Foreign Direct Investment and Income Inequality in Southeast Asia: a Panel Unit Root and Panel Cointegration Analysis, 1990-2013. Atlantic Economic Journal, 44(4), 411-424.

6. de Mello, L. R. (1997). Foreign direct investment in developing countries and growth: A selective survey. The Journal of Development Studies, 34(1), 1-34.

7. Eapen, A., Yeo, J., Sasidharan, S. (2019). Finance constraints and technology spillovers from foreign to domestic firms. Economic Modelling, 76, 50-62.

8. Ekmekçi, U., Ansal, H. (2009). Teknolojik yetkinliklerin doğrudan yabanc1 yatırımlardan bilgi transferine etkileri. The Impact of Technological Capabilities on Knowledge Transfer from Foreign Direct Investments., 8(4), 37-48. 
9. Ghebrihiwet, N. (2017). Acquisition or direct entry, technology transfer, and FDI policy liberalization. International Review of Economics \& Finance, 51, 455-469.

10. Güvenek, B., Alptekin, V. (2010). Enerji Tüketimi ve Büyüme İlişkisi: OECD Ülkelerine İlişkin Bir Panel Veri Analizi. 1(2), 172-193.

11. Ha, Y. J., Giroud, A. (2015). Competence-creating subsidiaries and FDI technology spillovers. International Business Review, 24(4), 605-614.

12. Im, K. S., Pesaran, M. H., Shin, Y. (2003). Testing for unit roots in heterogeneous panels. Journal of Econometrics, 115(1), 53-74.

13. Indicators | Data. (n.d.). Retrieved March 3, 2018, from https://data.worldbank.org/indicator

14. Kargi, B. (2014, March). Portfolio in Turkish Economy, and A Long Termed Relation Between Foreign Direct Investments and The Growth, and The Structural Breakage Analysis (1980-2012)

15. Levin, A., Lin, C.-F., James Chu, C.-S. (2002). Unit root tests in panel data: asymptotic and finite-sample properties. Journal of Econometrics, 108(1), 1-24.

16. Pedroni, P. (1999). Critical Values for Cointegration Tests in Heterogeneous Panels with Multiple Regressors. Oxford Bulletin of Economics and Statistics, 61(S1), 653670.

17. Pedroni, P. (2004). Panel Cointegration: Asymptotic and Finite Sample Properties of Pooled Time Series Tests With An Application To The Ppp Hypothesis. Econometric Theory, 20(3), 597-625.

18. Samuelson, P. A., Nordhaus, W. D. (2001). Macroeconomics (17th ed). Boston: Boston, Mass McGraw-Hill/Irwin.

19. Sandhu, N., Gupta, N. (2016). Determinants of Inward Foreign Direct Investment (1994-2014): The Case of India. SCMS Journal of Indian Management, 13(4), 83-94.

20. Song, S., Makhija, M., Lee, S.-H. (2014). Within-Country Growth Options Versus Across-Country Switching Options in Foreign Direct Investment. Global Strategy Journal, 4(2), 127-142.

21. Sunde, T. (2017). Foreign direct investment, exports and economic growth: ADRL and causality analysis for South Africa. Research in International Business and Finance, 41, 434-444.

22. Wilson, R. T., Baack, D. W. (2012). Attracting Foreign Direct Investment: Applying Dunning's Location Advantages Framework to FDI Advertising. Journal of International Marketing, 20(2), 96-115.

23. World Bank Country and Lending Groups - World Bank Data Help Desk. (n.d.). Retrieved March 4, 2018, from

24. https://datahelpdesk.worldbank.org/knowledgebase/articles/906519-world-bank country-and-lending-groups 